\title{
Bats of Bako National Park and Additional Notes on the Rare Partial Albinism in Fawn Roundleaf Bat (Hipposideridae: Hipposideros cervinus)
}

\author{
NUR MUKMINAH NAHARUDDIN ${ }^{1 *}$, NURSYAFIQAH SHAZALI ${ }^{2}$, RAHMAT LIBAR $^{2}$, \\ NUR FATIN KARIM ${ }^{2}$, MOHD RIDWAN A.R ${ }^{3}$, AZUAN ROSLAN ${ }^{2}$, MOHD ISHAM \\ AZHAR $^{2}$, MOHD ZACAERY KHALIK $^{2}, \&$ FAISAL ALI ANWARALI KHAN ${ }^{2 *}$ \\ ${ }^{1}$ Institute of Biodiversity and Environmental Conservation, ${ }^{2}$ Department of Zoology, Faculty of Resource \\ Science and Technology, ${ }^{3}$ Centre for Pre-University Studies, Universiti Malaysia Sarawak, 94300 Kota \\ Samarahan, Sarawak, Malaysia
}

\begin{abstract}
Bat survey was conducted in Bako National Park from $25^{\text {th }}$ to $29^{\text {th }}$ August 2013. A total of 107 individuals from 11 species of bats were recorded. Hipposideros cervinus was recorded as the most abundance species with 51 individuals while Murina suilla and Rhinolophus affinis were the least abundant with one individual each from total captures. This study has added $R$. affinis as another new species locality record for the national park. This brings up the total bat species known from the park now to 35 species of bats. Interestingly, an individual of $H$. cervinus with partial albinism was caught during this survey. This single bat was captured on the $27^{\text {th }}$ August 2013 and will be the first albino bat reported in Borneo and possibly Malaysia. This specimen is an adult female that presents high degree of albinism over most of the body but lacking on the upperparts of the body and part of the wings. Detailed description based on 16 external and craniodental measurements are presented herein along with their species identification through genetic analyses. Further research on the genetic structure and behavior of an albino individual may help to identify the possible causes and consequences of albinism to the bats populations.
\end{abstract}

Keywords: Chiroptera, Hipposideros cervinus, mammals, melanistic, Southeast Asia, species inventory

\section{INTRODUCTION}

National park and forest reserves are important for the purpose of conservation and management of flora and fauna. This is especially important for those species that are threatened and endemic. In Sarawak, there are at least 30 national parks, 10 nature reserves and four wildlife sanctuaries. Bako National Park is the oldest national park in Sarawak and it is known as one of the main tourist attraction, given that it is closest to Kuching city and easily accessible. One of the major attractions in this national park is the opportunity to see Proboscis Monkey that is endemic to Borneo. The park consists of seven different major habitats which includes heath forest, mangrove forest, mixed dipterocarp forest, riverine forest, beach forest, grassland and cliff vegetation (Hazebroek \& Abang Kashim, 2000).
Additionally, seasonal swamp forest also can be found around this park, as the intermediate between beach and mixed dipterocarp forest during the monsoon season (Khan et al., 2007). Combination of these different habitats provides diverse ecological niches for high species richness especially among the wildlife including bats (Khan et al., 2007).

Bats play a vital ecological role in the ecosystems. However this group of fauna is the most neglected order of land mammals worldwide and rarely featured on the priority list of any wildlife conservation program (Devkar et al., 2010). For example , the longtongued nectar bat (Macroglossus minimus) are known as one of the major pollinator for the mangrove trees which serve as the critical habitat for the iconic Proboscis Monkeys, besides birds and insects (Strahan, 1995;

*Corresponding authors: nurmukminah@gmail.com; akfali@unimas.my 
Bonaccorso, 1998; Lekagul \& McNeely, 1977; Payne et al., 1985;). Therefore attention should also be given to other fauna such as bats that ensure the stability of the ecosystem that is important for the popular iconic species (e.g. Proboscis Monkey and Orang Utan). Several bat studies including Start (1972), Francis et al. (1984), Churchill \& Zborowski (1987), Hall (1992), and Khan et al. (2007) have been conducted in Bako National Park. These studies were designed to update the species list and also to generally assess the population status of bats in the park that may potentially change due to recent climate change and increase of other threats such as deforestation and hunting. None of these studies documented incidence or discuss on albino bats or other albino wildlife in this national park.

Albino is a birth defect that potentially caused by genetic or environmental factors that alter the genetics. Albinism is a hypopigmentary congenital disorder known to affect a variety of mammals and other vertebrates (Uieda, 2000). It can be partial (leucism) with hypomelanism resulting in a variable distribution of melanin on the body and animals displaying white spots on the skin or white fur tufts on the body (Herreid \& Davis, 1960; Quay, 1970). Worldwide, only 70 complete-albino bats of 43 species have been recorded from 24 countries; with only a single albino bat has been noted in all the above cases (Brigham \& James, 1993; Uieda, 2000; Charles-Dominique et al., 2001; Barquez et al., 2003; Sodre et al., 2004; Aul \& Marimuthu, 2006; Oliveira \& Aguiar, 2008). In bats, partial and complete albinisms are quite rare (Sanchez-Hernandez et al., 2010). Most species of bats which albino individuals were recorded, including present study, occupy sheltered roosts like caves, mines, galleries and buildings. Such roosts may be essential for the survival of albino bats, to protect them against sunlight, water loss and predation by visually oriented predators (Aul \& Maritmuthu, 2006).

Although albinism scenarios in bats are rare, it is important to document the natural history information of these bats when possible. In this study, we provide an updated summary of list of species recorded in Bako
National Park since the last study six years ago by Khan et al. (2007). To provide the natural history information of the albino bat, we measured the skull and provide genetic data for species identification. Herein we discuss the result of our bat survey.

\section{MATERIALS AND METHODS}

\section{Study Area}

Bat survey was conducted in Bako National Park $\left(1.7167{ }^{\circ} \mathrm{N}, 110.4667{ }^{\circ} \mathrm{E}\right)$ in Kuching, Sarawak which covers an area of 2727 hectares. Bako National Park is located at Muara Tebas Peninsula on the north-eastern part of Kuching, about 37 kilometres away from Kuching city (Figure 1). The main access to the park is by 20 minutes boat-ride through Sungai Delima. Bako National Park is the oldest national park in Sarawak that was gazetted as a protected area on the $1^{\text {st }}$ May 1957. The survey was conducted around the park headquarters, part of Lintang trail, Ulu Assam trail, Serait trail, Teluk Delima trail, Tanjung Sapi trail, Teluk Paku trail and Teluk Assam trail.

\section{Field Methods}

A sampling survey was conducted from $25^{\text {th }}$ until $29^{\text {th }}$ August 2013 in Bako National Park. There were 10 mist nets and four four-bank harp traps were set throughout the sampling period. Nets and harp traps were checked for every two hours from 1830 until 1200 midnight and 0600 in the morning. Samples were identified following Payne et al. (1985). For each individual, standard measurements (Ear, Hind Foot, Tibia, Ventral tail length, Forearm, and Total length) and weight were recorded and representative of five individuals for each species were collected as voucher specimens. The samples were prepared as skin, skull and skeletal or as fluid wet specimen. These voucher specimen was deposited to the Universiti Malaysia Sarawak (UNIMAS) Zoological Museum.

\section{Laboratory Methods}

The skull and dental characters were measure to evaluate species identification and any other morphological anomaly. The skull of the 


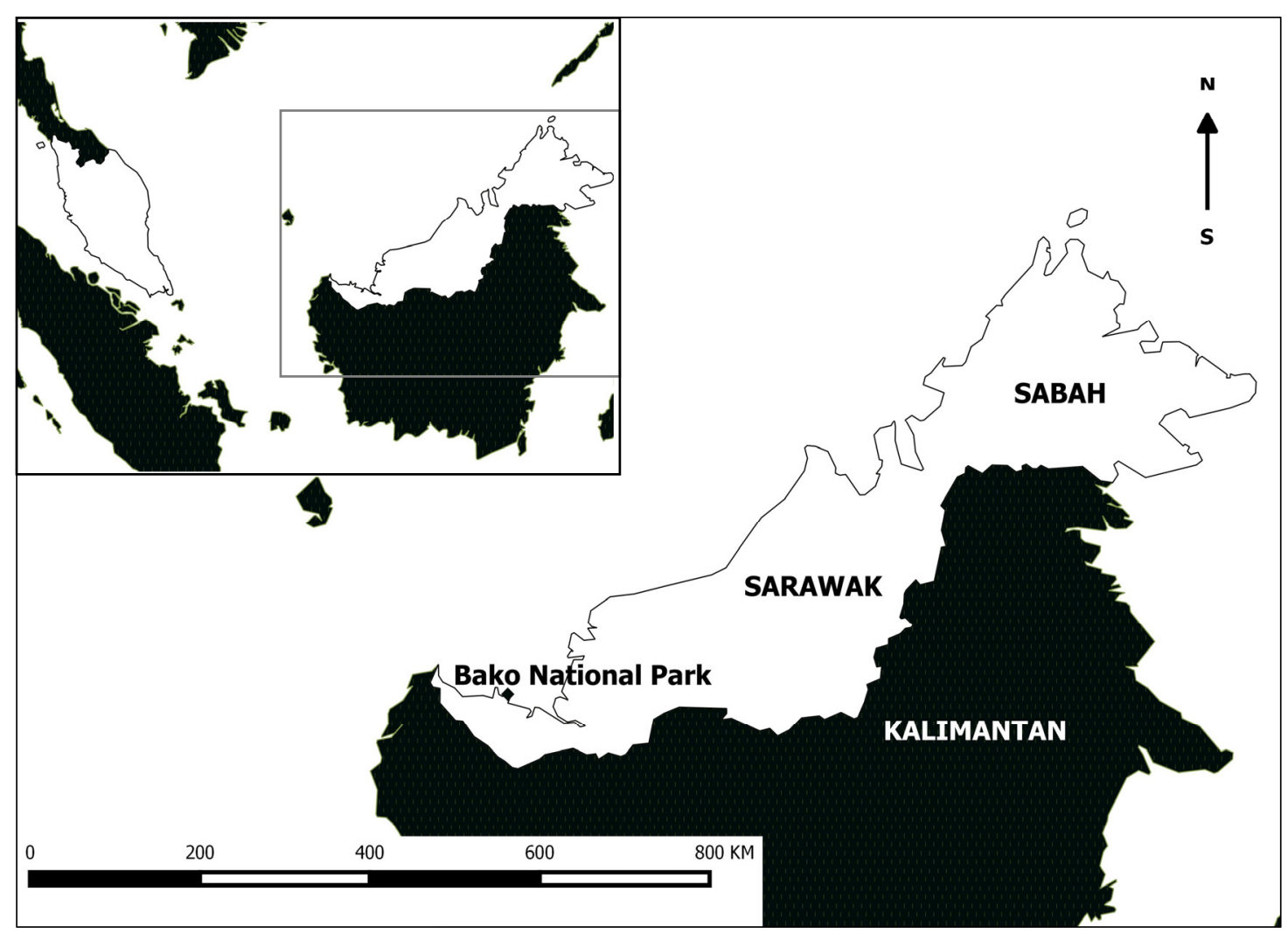

Figure 1. The figure show maps of Malaysia and the location of Bako National Park.

albino bat $H$. cervinus was extracted according to Nagorsen and Peterson (1980). The body, skull and dental measurements of the albino bat were measured following Kitchener et al. (1995) and Jayaraj (2008). Sixteen external characters and weight made using Mitutoyo digital caliper and Pesola, were recorded as follows; Forearm (FA), ear length (E), tibia length (TB), hind foot length (HF), Tail (T), Head body length (HB), second (D2MCL) and third digit metacarpal length (D3MCL), third digit first (D3P1L) and second phalanx length (D3P2L), fourth digit metacarpal length (D4MCL), fourth digit first (D4P1L) and second phalanx length (D4P2L), fifth digit metacarpal length (D5MCL), fifth digit first (D5P1L) and second phalanx length (D5P2L) and weight (WT).

Similarly, 17 craniodental characters were also measured using Mitutoyo digital caliper. The skull characters measured were the greatest skull length (GSL), postorbital width (POW), cranial width (CW), mastoid width (MW), zygomatic width (ZW), post palatal length (PPL), palatal length (PL), distance between cochlea (DBC), bulla length (BL), greatest basial pit length (GBPL), dentary length (DL), canine tooth basal width (C1BW), breadth across both canine outside surfaces (C1C1B), breadth across both third molar teeth outside surfaces (M3M3B), canine molar length or maxillary tooth row length (C1M3L), second molar tooth crown length (M2L) and the second molar tooth crown width (M2W). Additionally, we have generated genetic data to compare mitochondrial DNA sequence with other similar species.

The tissue of the albino bat was extracted using DNeasy tissue kit (Qiagen). Then, the amplification of the mitochondrial cytochrome $b$ (cyt $b$ ) was done using GenomiPhi DNA Amplification Kit (Amersham Biosciences/GE Healthcare) with the hot start PCR in a Biometra T-Gradient 96 thermal cycler in 25 $\mu 1$ reaction volumes $(1.0 \mu 1$ of DNA template was added to the initial mixture of $2.5 \mu \mathrm{l}$ of 10X buffer, $1.5 \mu 1$ of $\mathrm{MgCl}_{2}(25 \mathrm{mM}), 0.5 \mu 1$ of dNTP mix $(10 \mathrm{mM})$ and $1.0 \mu \mathrm{l}$ each of both forward and reverse primers, LGL765 (100 mM) (Bickham et al., 1995) and LGL766 (100 mM) (Bickham et al., 2004). Lastly, $14 \mu 1$ of $\mathrm{ddH}_{2} \mathrm{O}$ was added to complete the final 
mixture and added later with $0.2 \mu \mathrm{l}$ of Taq polymerase $(5 \mathrm{U} / \mu \mathrm{1})$. PCR products were sent to private laboratory for DNA sequencing. The sequence result were blast using the NCBI, Blast Assembled Genomes.

\section{RESULTS}

A total of 107 individuals representing 11 species from four families: Pteropodidae, Rhinolophidae, Hipposideridae and Vespertilionidae were recorded during the five trapping-nights in Bako National Park. Hipposideros cervinus was recorded as the most abundance species with 51 individuals while $M$. suilla and $R$. affinis were the least abundance with one individual each from the total captures. Rhinolophus affinis represent a new species locality record for Bako National Park (Figure 2). We also collected the Bornean endemic, $H$. coxi during this sampling (Figure 3). Single individual of partial albinism $H$. cervinus is caught in the harp trap (Figure $4 \mathrm{a}$ and $4 \mathrm{~b}$ ), along Teluk Paku Trail $\left(1.7167^{\circ} \mathrm{N}, 110.4667^{\circ} \mathrm{E}\right)$.

Data from previous studies were compared to show the species accumulation or reduction during different sampling occassions (Table 1). We have successfully recorded four families and 11 species of bats. In terms of species accumulation, it shows an increasing

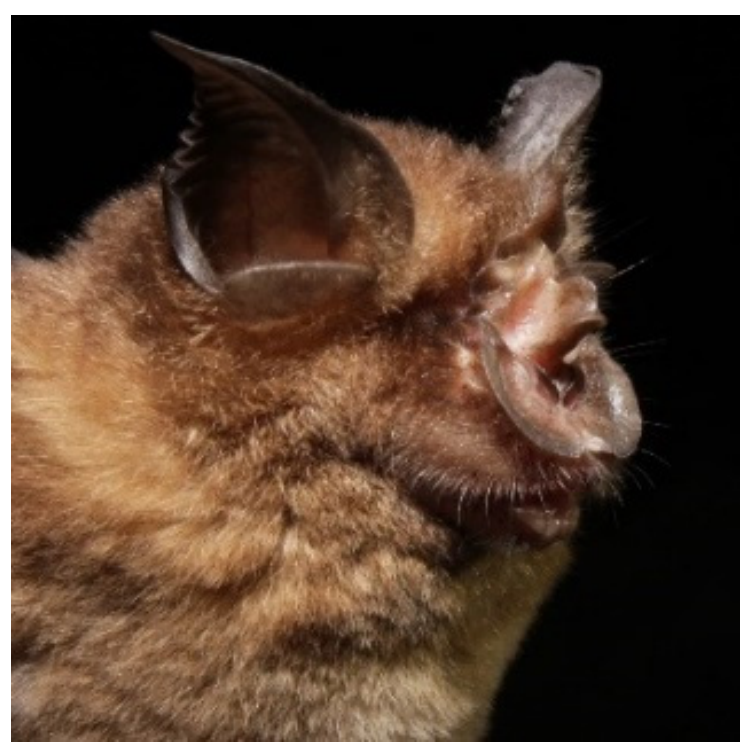

Figure 2. Portrait photo image of $R$. affinis from Bako NP.

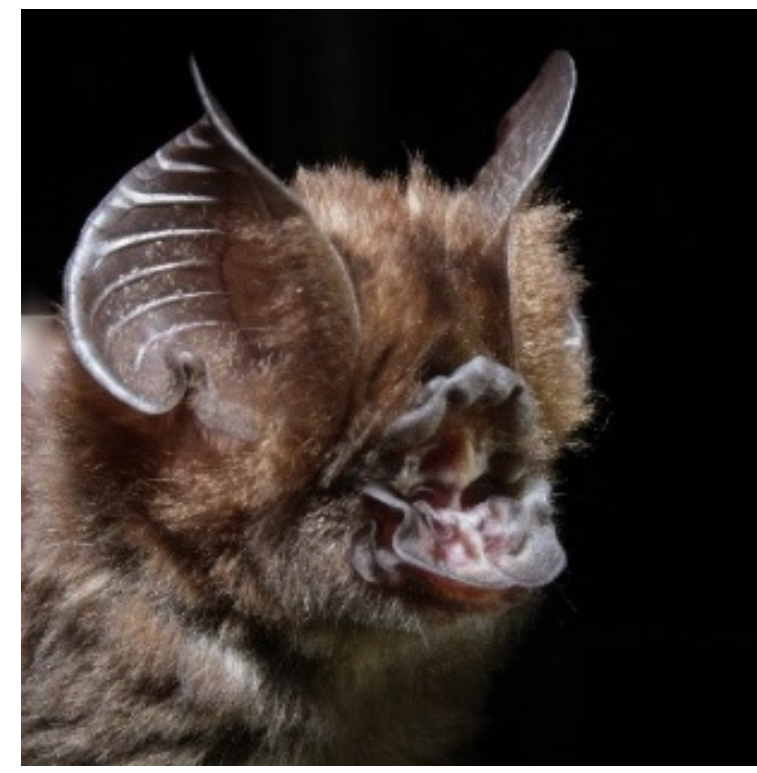

Figure 3. Portrait photo image of Bornean endemic H. coxi from Bako NP.

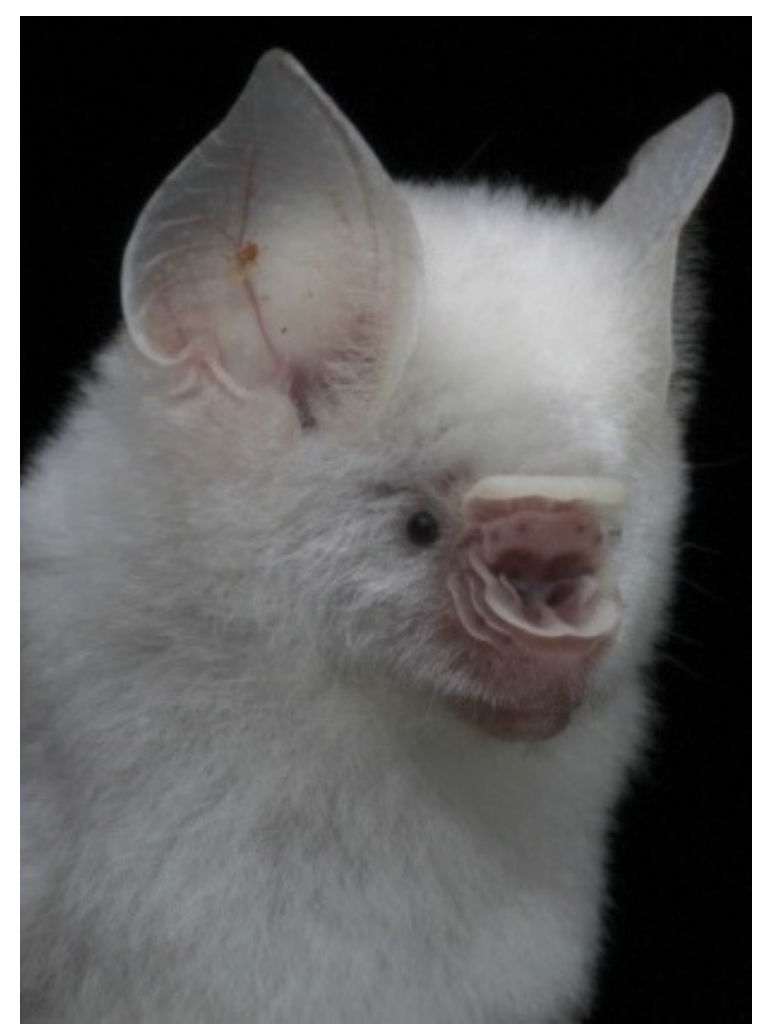

Figure 4(a). Portrait photo image of $H$. cervinus (albino) collected at Bako National Park. Redish eye could not been seen in the photo image but was observe in life specimens. The albino feature of $H$. cervinus has made the ears of $H$. cervinus appears to be translucent which is not observed in normal H. cervinus. 


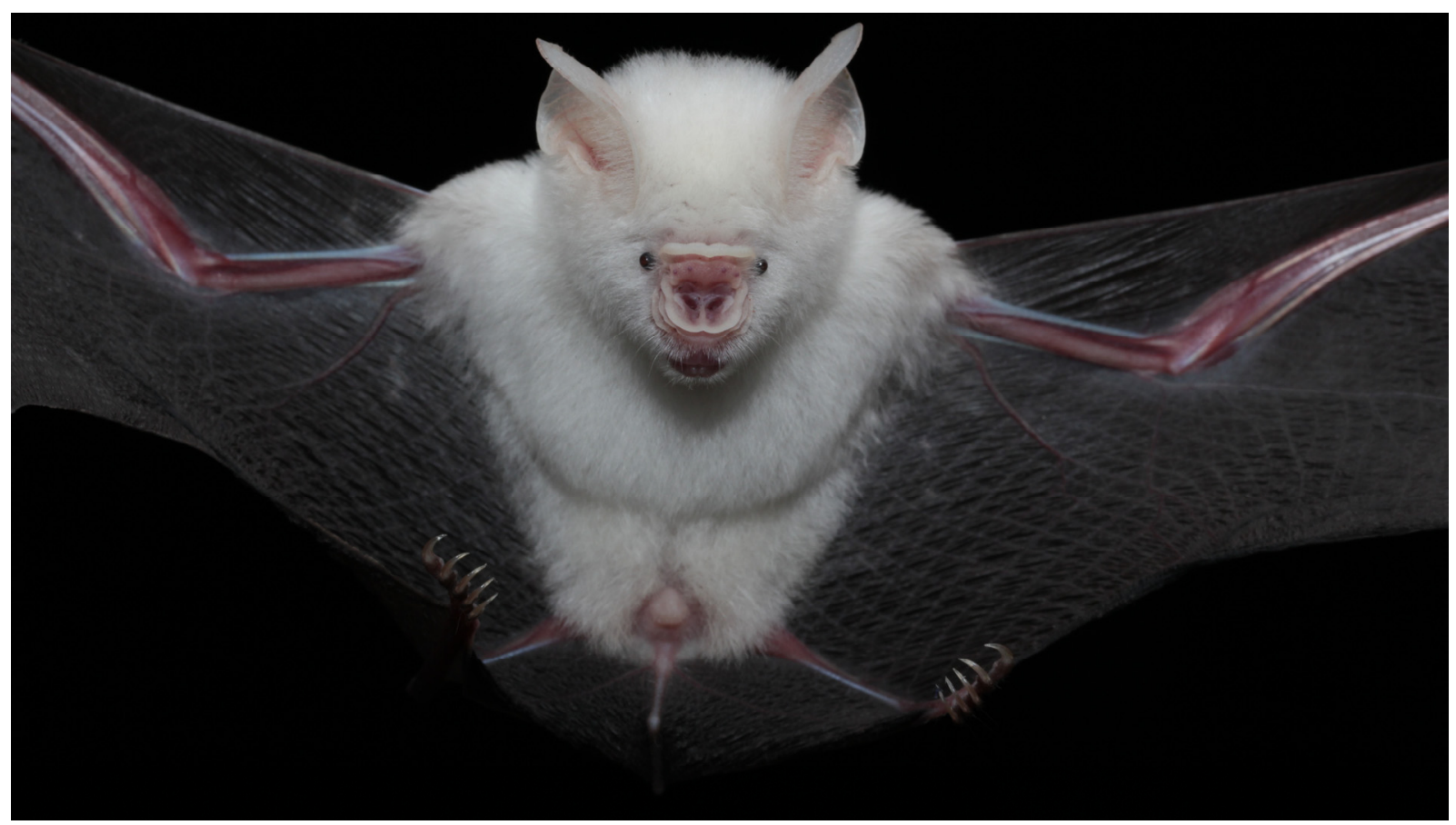

Figure 4(b). Full photo image of the $H$. cervinus (albino) from Bako National Park.

trend, while the number of individuals captured have decreased steadily over time. These result was tabulated and compared to previous studies on bats conducted in Bako National Park. Detailed description of the partial albino bat based on 16 external and craniodental measurements are presented herein (Table 2). The measurements are consistent with other $H$. cervinus from Sarawak (FA: 46.55 - 48.66; GSL: $17.66-$ 18.68; DL: $11.54-12.31)$ as listed in Sazali \& Juary (2012).

Additionally, our genetic analyses through Blast software also showed that our bat sequence matched $H$. cervinus. Then, the sequence was analyzed with MEGA using Kimura 2-parameter, with the available sequences on the cytochrome $b H$. cervinus in genebank. The genetic distance between the individuals shows a distance more than 5\%. This might be a distinct species, but it is hard for us to confirm it as the other individuals are from different locality.

\section{DISCUSSION}

This study has captured another bat species in the park, making the total number of bat species known from the park now to 35 species. Record of $R$. affinis in Bako National Park is not surprising as other bat species that are known roosting on rock crevices have been recorded before (e.g. $R$. borneensis; Emballonura sp.).

Therefore it is expected that many other rock or boulders roosting bats will be captured in the future. Record of $H$. coxi highlights the importance of Bako National Park as one their natural habitat as they are only known from Bau cave area (Wind Cave Nature Reserve, and Jambusan Cave; Ridwan et al., 2010) and Padawan area (Mount Penrisen; Khan et al., 2007). Hipposideros coxi is a rare species with data deficient status reported from IUCN Red List (Francis et al., 2008).

Albinism is considered as rare in bats, and mammals in general. Record of the partial albinism in $H$. cervinus is a significant finding for Bako National Park. This single bat was captured on the $27^{\text {th }}$ August 2013 and this will represent the first record of any albino bat reported in Borneo and possibly Malaysia at least for the species. Besides, this will be the first record for the $H$. cervinus as an albino. This specimen is an adult female that presents 
Table 1. List of bat species and their respective percentage relative abundance from Bako National Park, Sarawak.

\begin{tabular}{|c|c|c|c|c|c|c|c|}
\hline \# & $\begin{array}{l}\text { FAMILY } \\
\text { Species }\end{array}$ & $\begin{array}{l}\text { Current } \\
\text { Study } \\
(2015) \\
\end{array}$ & $\begin{array}{l}\text { Khan } \\
\text { et al. } \\
(2007) \\
\end{array}$ & $\begin{array}{c}\text { Hall } \\
(1992)\end{array}$ & $\begin{array}{c}\text { Churchill \& } \\
\text { Zborowski } \\
(1985)\end{array}$ & $\begin{array}{c}\text { Francis } \\
\text { et al. } \\
(1984)\end{array}$ & $\begin{array}{c}\text { Start } \\
(1972)\end{array}$ \\
\hline & PTEROPODIDAE & & & & & & \\
\hline 1. & Pteropus vampyrus & - & - & - & Sighted & - & - \\
\hline 2. & Cynopterus brachyotis & 2.80 & 7.12 & - & - & 6.98 & 11.63 \\
\hline 3. & Penthetor lucasi & 10.28 & 12.54 & - & 0.96 & 11.63 & 11.63 \\
\hline 4. & Balionycteris maculata & - & - & - & - & 6.98 & - \\
\hline 5. & Eonycteris spelaea & - & 10.17 & - & - & 37.21 & 6.98 \\
\hline 6. & Macroglossus minimus & - & 2.37 & - & 3.85 & 2.32 & 54.65 \\
\hline 7. & $\begin{array}{l}\text { EMBALLONURIDAE } \\
\text { Emballonura alecto }\end{array}$ & - & 0.34 & Recorded & 0.96 & 9.30 & - \\
\hline 8. & Emballonura monticola & - & 0.34 & - & - & - & - \\
\hline 9. & Saccolaimus saccolaimus & - & 0.34 & - & 1.92 & 6.98 & - \\
\hline 10. & Taphozous melanopogon & - & - & Recorded & - & - & - \\
\hline 11. & $\begin{array}{l}\text { MEGADERMATIDAE } \\
\text { Megaderma spasma }\end{array}$ & - & 0.34 & - & - & - & 3.49 \\
\hline 12. & $\begin{array}{l}\text { NYCTERIDAE } \\
\text { Nycteris tragata }\end{array}$ & - & 0.68 & - & - & - & 3.49 \\
\hline 13 & RHINOLOPHIDAE & 093 & - & - & - & $\ldots$ & - \\
\hline 14. & Rhinolophus borneensis & - & - & Recorded & - & - & - \\
\hline 15. & Rhinolophus philippinensis & - & - & Recorded & - & - & - \\
\hline 16. & Rhinolophus trifoliatus & 2.80 & 1.36 & - & 2.88 & 4.65 & - \\
\hline 17. & Rhinolophus luctus & - & 0.68 & - & - & - & - \\
\hline & HIPPOSIDERIDAE & & & & & & \\
\hline 18. & Hipposideros ater & - & 0.68 & - & - & - & - \\
\hline 19 & Hipposideros bicolor & - & 2.71 & - & - & - & - \\
\hline 20. & Hipposideros dyacorum & 5.61 & 1.02 & Recorded & 0.96 & - & - \\
\hline 21. & Hipposideros cervinus & 47.66 & 30.85 & Recorded & 50.96 & - & - \\
\hline 22. & Hipposideros galeritus & 14.95 & 7.12 & Recorded & 2.88 & 6.98 & 3.49 \\
\hline 23. & Hipposideros coxi & 1.87 & - & Recorded & 4.81 & - & 2.33 \\
\hline 24. & Hipposideros larvatus & 10.28 & 19.32 & Recorded & 20.19 & 4.65 & 2.33 \\
\hline 25. & Hipposideros diadema & - & 0.34 & Recorded & - & 2.32 & - \\
\hline & VESPERTILIONIDAE & & & & & & \\
\hline 26. & Myotis muricola & - & 0.34 & - & - & - & - \\
\hline 27. & Myotis ater & - & 0.68 & - & - & - & - \\
\hline 28. & Myotis horsfieldii & - & - & Recorded & - & - & - \\
\hline 29. & Myotis hasseltii & - & - & - & 1.92 & - & - \\
\hline 30. & Pipistrellus tenuis & - & - & - & 0.96 & - & - \\
\hline 31. & Pipistrellus vondermanni & - & 0.34 & - & - & - & - \\
\hline 32. & Murina suilla & 0.93 & - & - & 1.92 & - & - \\
\hline 33. & Kerivoula hardwickii & 1.87 & - & - & 4.81 & - & - \\
\hline 34. & Kerivoula pellucida & - & 0.34 & - & - & - & - \\
\hline 35. & Miniopterus australis & - & - & Recorded & - & - & - \\
\hline & Number of families & 4 & 7 & 4 & 5 & 4 & 4 \\
\hline & Number of species & 11 & 23 & 12 & 15 & 11 & 9 \\
\hline & Number of individuals & 107 & 295 & $\mathrm{Na}$ & 101 & 43 & 86 \\
\hline & Trapping-nights & 5 & 226 & $\mathrm{Na}$ & 64 & 39 & 72 \\
\hline
\end{tabular}

* = New record from this study, $\mathrm{Na}=$ data not available, $(-)=$ not recorded in the respective study, Recorded $=$ identified based on echolocation call not captured. 
Table 2. External and Craniodental measurements $(\mathrm{mm})$ of the albino $H$. cervinus $\left({ }^{*}\right)$ individual and other $H$. cervinus individual $(\mathrm{n}=1)$ in Bako National Park from this survey.

\begin{tabular}{lcclccc}
\hline \multirow{2}{*}{$\begin{array}{c}\text { External } \\
\text { Characters }\end{array}$} & \multicolumn{2}{c}{ Measurements } & \multirow{2}{c}{$\begin{array}{c}\text { Craniodental } \\
\text { characters }\end{array}$} & \multicolumn{2}{c}{ Measurements } \\
\cline { 2 - 3 } & Albino* & Other & & Albino* & Other \\
\hline FA & 44.06 & 47.80 & GSL & 17.50 & 18.23 \\
E & 14.06 & 14.92 & POW & 2.71 & - \\
T & 27.59 & 25.08 & CW & & 7.77 & 7.76 \\
WT & 6.0 & - & MW & & 8.26 & 9.28 \\
TB & 15.34 & 17.82 & ZW & & 9.72 & 8.24 \\
HB & 46.27 & - & PL & 6.06 & 5.94 \\
HF & 5.67 & 6.20 & PPL & 8.10 & 25.46 \\
D2MCL & 37.11 & - & DBC & 3.67 & 4.97 \\
D3P2L & 15.24 & 16.47 & BL & 2.23 & 2.56 \\
D3P1L & 15.89 & 15.24 & GBPL & 4.62 & 7.51 \\
D3MCL & 33.67 & 36.83 & DL & 11.45 & 12.02 \\
D4P2L & 9.02 & - & C1BW & 1.20 & 2.50 \\
D4P1L & 10.42 & - & C1C1B & 3.81 & 3.77 \\
D4MCL & 32.19 & 35.10 & M3M3B & 6.47 & 20.18 \\
D5P2L & 9.23 & - & C1M3L & 6.25 & 6.48 \\
D5P1L & 12.69 & - & M2L & 1.41 & 4.50 \\
D5MCL & 29.22 & 31.12 & M2W & 1.67 & 1.74 \\
\hline
\end{tabular}

a high degree of albinism over most of the body but lacking at the upperparts of the body and part of the wings. Record of this albino bats indicates that there was an important roosting site in Bako National Park for this individuals to survive because albino individuals are known to be not able to resist sunlight due to lack of melanin pigmentation.
Hipposideros cervinus is known from multiple fur colour variation within the species including brown, orange, and grey (Figures 5ac). However record of white fur coloration here do not represent a new colour form for the species or a separate species. This only indicate the occurrence of partial albinism in that individual.

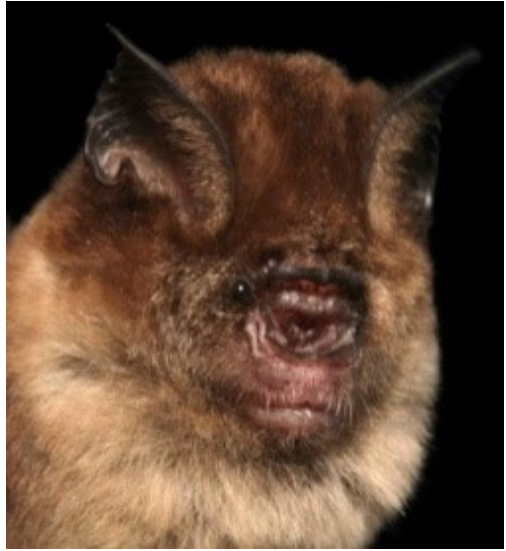

Figure 5(a). Portrait photo image of $H$. cervinus (Brown form).

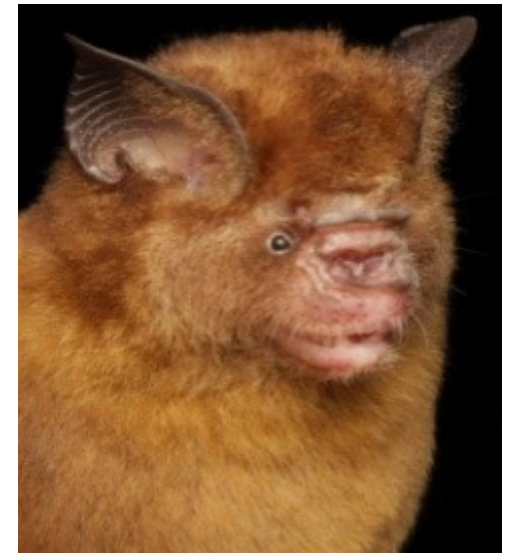

Figure 5(b). Portrait photo image of $H$. cervinus (Orange form).

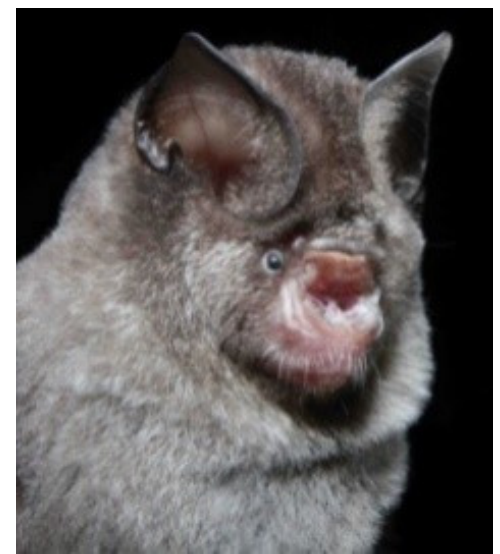

Figure 5(c). Portrait photo image of $H$. cervinus (Grey form). 


\section{CONCLUSION}

This survey has documented 11 species of bats with the additional new record of $R$. affinis and also an albino $H$. cervinus individual. Further research should be done on the genetic structure and behavior of an albinism individual, and may help identify the possible causes and consequences to the bats populations.

\section{ACKNOWLEDGEMENTS}

This study is supported by the research funding from two grants, namely SGS - 01 $(\mathrm{S} 130 \mathrm{a}) / 1025 / 2013 \quad$ (15) and 01 (S130)/1024/2013 (14) awarded to FAAK and MZK. We also like to thank the Sarawak Forestry Department for granting the research permit no. NCCD. 907. 4. 4 (Jld.)-147. Finally thanks to all Sarawak Forestry Corporation personnels for their warm hospitality during our field samplings and kind permission to use the facilities and conduct research in the park.

\section{REFERENCES}

Aul, B. \& Marimuthu, G. (2006). Sighting of an albino bat in a colony of cave-dwelling microchiropteran, Hipposideros diadema nicobarensis at the Nicobor Islands. Current Science, 90: 912-914.

Barquez R.M., Carrizo, L.V., Ferro, L.L., Flores, D.A., Mollerach, M.I., Sanchez, M.S., \& Garcia Lopez, A.P (2003). Primer caso de albinismo total para Sturnira erythromos (Tschudi, 1844) - (ChiropteraPhyllostomidae). Chiroptera Neotropical, 9: 166-169.

Bickham, J.W., Patton, J.C., Schlitter, D.A., Rautenbach, I.L., \& Honeycutt, R.L. (2004). Molecular phylogenetics, karyotypic diversity, and partition of the genus Myotis (Chiroptera: Vespertilionidae). Molecular Phylogenetics and Evolution, 33: 333-33.

Bickham, J.W., Wood, C.C., \& Patton, J.C. (1995). Biogeographic implications of cytochrome $b$ sequences and allozymes in sockeye (Oncorhynchus nerka). Journal of Heredity, 86: 140-144.

Brigham, M. \& James A.K. (1993). A true albino little brown bat, Myotis lucifugus, from Saskatchewan. Saskatchewan, Canada: Blue Jay Publication. Pp 213-214.

Bonaccorso, F.J. (1998). Bats of Papua New. Guinea. Conservation International Tropical. Field Guide Series, Conservation International, Washington, D.C.

Charles-Dominique P., Brosset, A., \& Jouard, S. (2001). Atlas des chauves-souris de Guyane. Paris: Museum d'Histoire Naturelle Publication.

Churchill, S. \& Zborowski, P. (1987). Bat survey of Bako National Park, Sarawak. The Sarawak Museum Journal, 32(58): 171-179.

Devkar, R.V., Sapna, J., Kartik, U., \& Pritesh, P. (2010). Albino microchiropteran, Rhinopoma microphyllum kinneri sighted in a bat colony inhabiting abandoned mines. Current Science, 100(2): 165-166.

Francis, C., Kingston, T., \& Gumal, M. (2008). Hipposideros coxi. The IUCN Red List of Threatened Species 2008.

Hazebroek, H.P. \& Abang Kashim, A.M. (2000). National Parks of Sarawak. Natural History Publications (Borneo), Kota Kinabalu.

Herreid, C.F. \& Davis, R.B. (1960). Frequency and placement of white fur on free-tailed bats. Journal of Mammalogy, 117-119.

Jayaraj, V.K. (2008). The phylogenetic relationship of megachiroptera in Malaysia inferred from morphological and DNA analyses, MSc Thesis. Universiti Malaysia Sarawak, Kota Samarahan, Malaysia. 
Khan, F.A.A, Sazali, S.N., Kumaran, J,V., Aban, Siali., Zaini, M.K., Ketol, B., Ryan, J.R., Julaihi, A.M., Hall, L.S., \& Abdullah, M.T. (2007). Bats of Bako National Park, Sarawak, Malaysian Borneo. The Sarawak Museum Journal, 84: 267-300.

Kitchener, D.J., Packer, W.C., \& Maharadatunkamsi. (1995). Morphological variation in Pteropus lombocencis (Chiroptera: Pteropodidae) in Nusa Tenggara. Indonesia. Records of the Australian Museum, 17: 61-67.

Lekagul, B. \& McNeely, J.A. (1977). Mammals of Thailand. Association for the Conservation of Wildlife, Sahakarnbhat, Co., Bangkok. Pp 758.

Nagorsen, D.W. \& Peterson, R.L. (1980). Mammal collector's manual. Royal Ontario Museum, Toronto: Life Sciences Miscellaneous Publication.

Oliveira, H.F.M. \& Aguiar, L.M.S. (2008). A new case of complete albinism in a bat from Brazil. Chiroptera Neotropical, 14: 421-423.

Payne, J., Francis, C.M., \& Phillipps, K. (1985). A field guide to the mammals of Borneo. Kota Kinabalu: The Sabah Society and World Wildlife Fund Malaysia Publication.

Quay, W.B. (1970). Integument and derivatives, p.1-56. In: W.A. Wimsatt (Ed). Biology of bats. New York: Academic Press Publication.
Ridwan, M.A.R., Tingga, T.R.C., Hasan, N. H., Wiantoro, S., Achmadi, A.S., Lit, E. Ketol, B., Husin, H.I. \& Abdullah, M.T. (2010). Diversity of bats in two protected limestone areas in Sarawak, Malaysia. The Sarawak Museum Journal, 88: 210-246.

Sanchez-Hernandez, C., Romero- Almaraz, M., Taboada-Salgado, A., AlmazanCatalan, A., Schnell, G.D., \& SanchezVasaquez, L. (2010). Five albino bats from Guerro and Colima, Mexico. Chiroptera Neotropical, 16: 541-545.

Sazali, S.N. \& Juary, J. (2012). Morphometric Analysis of the Fawn Roundleaf Bat, Hipposideros cervinus (Gould, 1854) (Chiroptera: Hipposideridae), from several population in Sarawak. Tropical Natural History, 12(1): 89-95.

Sodre, M.M., Uieda, W., \& Baldim, M. (2004). First record of albinism in the bat Eumops glaucinus (Mollosidae) from southeastern Brazil. Chiroptera Neotropical, 10: 200-201.

Start, A.N. (1972). Some bats of Bako National Park, Sarawak. The Sarawak Museum Journal, 20: 371-376.

Strahan, R. (1995). The mammals of Australia. Chatswood, New South Wales, Australia: Reed Books Publication.

Uieda, W. (2000). A review of complete albinism in bats with five new cases from Brazil. Acta Chiropterologica, 2: 97-105. 